\title{
Influence of Smriti Texts to Women Leadership Development in Cooperatives
}

\section{Sita Dhungana*}

\begin{abstract}
The patriarchy under Hindu tradition has been an issue of shaping role of female in present society. Their role in the family and in the society has been taken as supportive on financial mobilization rather in leading position as compared to men. Financial mobilization through cooperatives has been accepted as a key component for economic development of Nepalese community. It may be the appropriate way of increasing income, generating employment opportunities and eradicating poverty. This study has aimed at analysing the relationship of female leadership within the circumstances of Hindu tradition, cooperative movement, and analyzed the effect of intervention factors of financial mobilization. This article has been prepared after the analytical review of Hindu ancient literatures and present policies, social customs and traditions. Information was analyzed and impact of the variables on female leadership was assessed. The result has demonstrated that the Hindu tradition has an average positive influence on financial mobilization, while investment opportunities and intervening variables have a strong positive influence on empowering women leadership in cooperatives. The Smriti texts including Manu Smriti texts were the factors that hindered the Nepalese women to take part the leadership role in their family and the community.
\end{abstract}

Keywords : women's leadership, role effectiveness, social inclusion, SDG, financial mobilization, transformational leadership

* Sita Dhungana is Vice Chair of Gajuri Rural Municipality. She is a Ph.D. scholar as well. Email: sitadhng@gmail.com 


\section{Introduction}

Nepalese society has been descended from and guided by ancient Hindu traditions. The Hindu tradition has been an influencial environment for women's lead role to be played even in present context (Afful, 2002). It has been an issue of making setbacks to Nepalese Hindu women from historic times. There has been quite growing interest in the ethical behavior of women's leadership. Initially, leadership in finance sector was considered as an act of altruism in welfare society. This was a selfless concern for the benefit of others. In the modern day, it has been the manifestation of the notion of inclusive empowerment to good causes. From a concern, initially focused on financial issues has now taken to more recent inclusion of other social issues such as human rights. But not clear precisely how widely society is defined in terms of the size of the community to which the organisation is or should be responsible. Cooperative members may be broadly or narrowly conceived. Cooperative participation seems to be mainly restricted to an involvement in local community or within the firm itself as opposed to a concern for women empowerment in global context (Nelson \& Thomsen, 2010). The Hindu Smriti texts including Manu Smriti have a negative influence on the female role. It has been necessary to analyze from the perspective of present day female leadership in cooperatives under the consequences of the tradition and role of female in financial management. This paper has pointed out the influence of Smiriti texts to women leadership development in cooperatives.

\section{Objectives}

The main objective of this study is to analyze the influence of Smriti texts on the role effectiveness of women leadership in cooperatives. The specific objectives are:

1. To explore the status of women leadership for financial management within the frame of cooperative society in the context of Manu Smriti and other relevant Smriti texts of Hindu traditions of Nepal and

2. To analyze the performance of women under Manu Smriti and other relevant Smriti texts of Hindu tradition and present practice in their leadership to manage cooperative sector. 


\section{Literature review}

Some research works made by previous researchers have been reviewed in the study to develop some theoretical background and conceptual framework. The 'Smriti'era (600-200) BC and thereafter the religious and cultural practices have determined female with the supportive role in the family concerning financial mobilization. The author concentrated on the provisions earliest to late Smriti phases of Hindu tradition (Smriti corpus) including the six Vedangas (grammar, meter, phonetics, etymology, astronomy and rituals), the Itihasa (literally means 'so indeed it was'), epics (the Mahabharata and Ramayana) and the texts on the four proper goals or aims of human life:

Dharma: These texts discuss dharma from various religious, social duties, morals and personal ethical perspective. Each of six major schools of Hinduism hasits ownliterature on dharma. Examplesinclude Dharma-sutras including by Gautama, Apastamba, Baudhayana and Vashistha) and Dharma-sastra particularly Manusmriti, Yajnavalkya Smriti, Naradasmriti and Visnusmriti. At personal dharma level, this includes many chapters of Yogasutras.

Artha: Artha-related texts discuss artha from individual, social and as a compendium of economic policies, politics and laws as the Arthashastra of Chanakya, the Kamandakiya Nitisara, Brihaspati Sutra, and Sukra Niti. Olivelle (2013) states that most Artha-related treatises from ancient Nepal have been lost.

Kaama: These discuss arts, emotions, love, erotics, relationships and other sciences in the pursuit of pleasure. The Kamasutra of Vatsyayana is most well known. Others texts include Ratirahasya, Jayamangala, Smaradipika, Ratimanjari, Ratiratnapradipika, Ananga Ranga among others.

Moksha: These develop and debate the nature and process of liberation, freedom and spiritual release. Major treatises on the pursuit of moksha include the later Upanishads (early Upanishads are considered Shruti literature), Viveka- chudamani, and the sastras on Yoga. Similarly, the Puranas (literally, of old), the Kavya or poetical literature, the extensive Bhasyas (reviews and commentaries on Shrutis and non-Shruti texts), the sutras and shastras of the various schools of Hindu philosophy and the numerous Nibandhas 
(digests) covering politics, medicine (Charaka Samhita), ethics (Nitisastras), culture, arts and society (Lochtefeld, 2002).

Around 2000 years before, classical Hinduism, or present day Hindu tradition started crystallizing. Worship of the supreme being through icons and sacred symbols was started and different religious cults developed out of which the Shakta tradition specifically worships the divine as the mother of the universe. Women were accorded the status of goddess in textual Hinduism. Like other religions, Hinduism is not limited to a set of beliefs or propositional truths or practices. In practice, Hinduism can not credit itself of being fair to its women. Injunction is with the Smritis. These Smritis often reveal some teachings that are derogatory to women in various ways. However, the real position of women in the Hindu society has been better than what is ordained by these texts, and vice versa as well most of the time (Narayanan, 1999). From this point of departure, it has been a matter of discussion that the Smriti texts including Manu Smriti have been a long time setback for coming out as a leading role in the family and in the society focusing on financial management rather than having a supportive role.

Four components need to be present for a cooperative management. It is socially responsible affair. These are economic, legal, ethical, and philanthropic responsibilities. The women leadership has been increased across the globalised world. It makes sound relationship with society. It has goals to extend the activities of the organizations. It encourages positive environment and inclusive participation in society, states and other socioeconomic realms. Most cooperative societies have applied leadership development and women's empowerment concept in own activities. The increase in the demand for financial services has brought changes in their participation forfinancial mobilization in cooperatives. It has been an important topic in financial, economic and social science disciplines. Similarly, local and international organisations have continued to explore the best modalities regarding the application of cooperative concept to almost every area of the economic needs of individuals at urban and rural areas. This may have necessitated the declaration of the year 2005 as the international year of microcredit and the year 2012 as the international year of cooperatives by the United Nations' General assembly (ILO, 2009).

Cooperative is regarded as a social business organization which is operated by the group of people for their mutual benefits. It is a kind of teamwork which enhances interpersonal skills of members to work in group as a member of cooperative. It has been world widely proven that team work is 
the key to success. Cooperative models are being applied not only in Nepal, even the developed countries of the world have succeeded in their goal achieving tasks applying the same model of cooperative. The concept of cooperative was practically implemented in Nepal since 1963. During the preliminary phase of cooperative, very few people had taken initiation to be duly involved in this field. Within the span of 52 years, 32,663 cooperatives have already been incorporated and have been successfully running their activities in society in which 5.1 million people are actively involved as individual members. Amongst the active members, 267,722 are enlisted as directors where 91,196 are women leading the cooperative organizations (DoC, 2017).

\section{Method}

Various relevant literatures were analyzed as a part of designing this research, and getting in-depth knowledge about the subject of study (Kothari, 2004). The office records of cooperatives such as Operational Plans, Users' Constitutions, Minute books, reports such as district profiles, bulletins etc, records of Department of Cooperatives such as audit related files, monitoring and evaluation records, databases, were also the sources of information. Various literatures on lead role of women in Hindu tradition, leadership role effectiveness in financial mobilization and cooperative society management including journal published by cooperative society and federations, annual report published by Department of Cooperatives and Survey, various women leadership related strategies, Cooperative Act 2011, Cooperative Regulation 2012, Cooperative Guidelines 2013 and Policy 2014 were analyzed for the study.

\section{Results and findings}

The study has been conducted focusing on women leadership in traditional financial mobilization focusing on the practices of profit making cooperative houses. Rare researches are available on the women leadership and its effectiveness in cooperative organizations in Nepalese context. Conflicting and controversial results have been produced in different geographical locations about the impact of women led cooperative management.

According to Central Bureau of Statistics 2011, female population is about $51 \%$ of the total population in Nepal. They need a leadership position. 
Some cooperatives with women leaders are successful in running organizations. There might be possibility to identify and starting of good practice. The study may provide insight to improve social harmony and inclusion.

The government has adopted flexible cooperative friendly policy of public private partnerships in different modalities and they need to be assessed for proper guidance. There is confusion of using cooperatives as cooperative organization or social organization for the community welfare and needs concrete policy for the socio economic promotion of the women. Success and failure of women's leadership in cooperative management demand research to explore what works and what not. The present study may have substantial importance for the following sector:

1. This study may contribute for the baseline information about traditional practice of women's leadership on financial mobilization and cooperative management in different sectors including saving credit, agricultural, health and education cooperatives as well as multipurpose cooperatives in Nepal.

2. This study may be helpful for educational planner, policy maker and social science specialists.

3. In the same way, government agencies, NGOs and INGOs may have an input to plan and execute the program to be addressed to uplift women's leadership on cooperative management.

4. This study may be useful to researchers, university teachers and students.

The study may bring insightful analysis of women's participation in the financial management of cooperatives and its impact on the women's leadership promotion and sustainability measure to the management of resources. It also brings significant results for making long term cooperative sector policy in relation to equitable benefits sharing among the cooperative members, particularly for the disadvantaged sector of the society focusing on women leadership. The research result also can be crucial for students, researchers, and policy makers to make decision bringing poor and disadvantaged people with the scope of policy frame.

\section{Position of women in Hindu literature}

Manusmriti, Ramayana, Mahabharata, Upanishads, and Geeta are important 
parts of Hindu Literature. Manusmriti, known as Manav Dharam Shastra, is the earliest work on Brahminical Dharma in Hinduism. According to Hindu mythology, the Manusmriti is the word of Brahma, and it is classified as the most authoritative statement on Dharma. The scripture consists of 2,690 verses, divided into 12 chapters. Hindu consider the Manusmriti as the divine code of conduct and, accordingly, the status of women as depicted in the text has been interpreted as Hindu divine law. In Vedic era, birth of a male was regarded a source of women empowerment and Hindu Literatures prioritize it than the birth of a female child. For instance, in Rig Veda, there is a prayer for the birth of a son. In Brahmnas, the birth of son was greatly favoured. The Atharva Veda clearly mentions the unpleasantness at the birth of girl as it was prayed to God that kindly grant birth of boy here and grants the birth of girl somewhere else. Manu did not treat women at par with men. Manu was the father of Hindu religion. He made the condition of women miserable and pathetic. He formulated and implemented various laws which made condition of women miserable. He wrote book Manusmriti containing the laws for the oppression of women and shudras. But even today the laws of Manusmriti are being followed strictly. Some of the 'celebrated' derogatory comments about women in the Manusmriti are as:

1. It is the nature of women to seduce men in this world; for that reason, the wise are never unguarded in the company of females (2: 213).

2. Women, true to their class character, are capable of leading astray men in this world, not only a fool but even a learned and wise man. Both become slaves of desire (2: 214).

3. Wise men should not marry women who do not have a brother and whose parents are not socially well known (3:10).

4. A Brahman, true defender of his class, should not have his meals in the company of his wife and even avoid looking at her. Furthermore, he should not look towards her when she is having her meals or when she sneezes/yawns (4: 43).

5. A Brahman in order to preserve his energy and intellect, must not look at women who applies collyrium to her eyes, one who is massaging her nude body or one who is delivering a child (4:44).

6. A female child, young woman or old woman is not supposed to work independently even at her place of residence (5:150). 
7. Girls are supposed to be in the custody of their father when they are children, women must be under the custody of their husband when married and under the custody of her son as widows. In no circumstances is she allowed to assert herself independently (5:151).

8. Men may be lacking virtue, be sexual perverts, immoral and devoid of any good qualities, and yet women must constantly worship and serve their husbands (5:157).

9. Women have no divine right to perform any religious ritual, nor make vows or observe a fast. Her only duty is to obey and please her husband and she will for that reason alone be exalted in heaven (5:158).

10. Any women violating duty and code of conduct towards her husband, are disgraced and becomes a patient of leprosy. After death, she enters womb of Jackal (5:167).

11. Since women are not capable of living independently, she is to be kept under the custody of her father as child, under her husband as a woman and under her son as widow (9:3).

12. It is the duty of all husbands to exert total control over their wives. Even physically weak husbands must strive to control their wives (9: 6).

13. Consuming liquor, association with wicked persons, separation from her husband, rambling around, sleeping for unreasonable hours and dwelling- are six demerits of women (9: 13).

14. While performing Vedic mantras are not to be recited by women, because women are lacking in strength and knowledge of Vedic texts. Women are impure and represent falsehood (9: 18).

15. In case of any problem in performing religious rites, males between the age of 24 and 30 should marry a female between the age of 8 and 12 (9: 93).

16. God Indra said "Women cannot be educated because they are always stupids" (Rigvaeda, 8:33 and 17).

17. Friendship cannot be made with women because their hearts are like the hearts of leopards (Rigveda, 10: 95 and 15).

18. Women, Shudras, Dogs and Crows are big liars (Yajurveda, 6/5/8/2) 
19. Women give sorrows (Atharvaveda, 7: 3 and 11)

20. A father should arrange marriage of his daughter before she gets the age of 12 years. If father does not follow this rule he is a great sinner. This supports child marriage (Prashar Smriti).

Though the present constitutional provisions, existing rules and regulations have denied the disparities of female, the discriminatory verses are still popular and believed by the people as a part of culture. It may take time to remove these barriers in successive generations by leadership practices including cooperative leadership.

\section{Role of female under Smriti}

During $500 \mathrm{BC}$ to $500 \mathrm{AD}$, the position of women further deterirate. In the history of Nepal, these dark and depressing days of total injustice, intolerance and inequality werethe darkest spot forever. There were varied and many reasons for the deterioration or fall in the position of women. The only good thing that developed during this period was the recognition of certain proprietary rights for women. It is Manu's code that has had the most negative impact on Nepali Women for countless succeeding generations. Even today, it is his laws which keep millions helpless in the prison of Hindu orthodoxy. Manu for the first time legally assigned woman to her definite place in the scale of society. But his laws reflect a conflict between his valuation of woman as a spiritual entity on the one side and as a unit in society on the other. He averred that a mother is more to be revered than a thousand fathers, yet his laws place women socially on a level with the lowest of all groups in Aryan society, the Sudra. Manu enumerates many laws directing a wife's conduct. He says that a wife must show to such devotion to her husband that he must be treated like God, even when he is conspicuously lacking any virtue whereas no sacrifice, no vow, and no fast must be performed by their husbands for the wives. If a wife obeys her husband, she will for that (reason) be exalted in heaven. In childhood, a female must be subject to protection by her father, in youth by her husband. When her spouseis dead she is supposed to be protected by her sons. A woman must never be independent. The laws of Manu state that women were created to be mothers and that they may perform religious rites along with their husbands. Yet there are some passages which deny to women the privilege of offering sacrifices. In the period of later Smrities women were deprived of any right to justice, freedom, education, equality and were degraded domestically, socially, legally, economically, politically 
and in every other way. They came to be called Abala (the powerless) or Griha pinjara kokila (Cuckoo of the cage of the house) and subject to the most derogatory maxim; Putrartha Kriyate Bharya (women has to be taken in marriage for procreation only).

\section{Stridhan according to the Smritikars}

Manu: According to a text of Manu, there can be no property belonging to woman, Son or a slave and whatever property is earned by them, belongs to that person to whom the woman or slave belongs. It does not mean that they cannot own any property rather it means that they cannot alienate the property. Manu's view has also been supported by Gautam. He observed that a woman can own separate property but she cannot alienate the same. According to Manu Adhyagni (whatever has been given at the time of nuptial fire), Adhyavahanika (whatever has been given at the time of departure of wife), Dattamprite karmani (given out of love and affection) and given by the father, mother or the brother, all these are six types of gifts which come under the term Stridhan. According to Vishnu, anything given to a woman by her father, mother, sons and brothers or whatever is received by her at nuptial fire, or whatever she receives from her husband at remarriage, or what she receives from her relatives and the gifts received by her after marriage is stridhan. According to Yagyavalkya, to the above list enumerated by Manu and Vishnu, the word 'adi' etc. has been added by Yajyavalkya. Vijyaneshwara, a commentator of Yajyavalkya Smriti, has enlarged the list of properties coming under stridhan due to the use of this word 'adi'. He includes in the list all such properties acquired through gift, sale, partition other lawful means. Katyayana too while enumerating six kinds of stridhan, identified two more things, under it earning through art and gifts received during unmarried state and those gifts received when the bride went to bride's home as also those which was received by her during her widowhood. According to him, father, husband, son or brother do not have a right to use or alienate the property falling under stridhan of a woman. Any body who uses the property without woman's consent is liable to return it with interest and will also have to pay fine to the king. In case of distress of husband or when he suffers from any disease or is being tortured by the creditors, the woman can herself voluntarily contribute out of the stridhan but the husband should reimburse her later on. Other Smritikars like Apastamba, Vyas and Deval too have discussed the stridhan on the similar lines. Upon composite study of the views of these Smritikars on stridhan, Adhyagni, Adhyavahanik, Pritidatt and gifts given by the father, 
brother or mother or relatives in shape of money, Adhivednik, Shulk, or Anivadheya can be referred to as stridhan.

\section{Early encounter of women with modernity}

Hindu women's early encounters with modernity occurred in the context of the British colonization in the nineteenth and early twentieth centuries through what are known as Hindu Reform Movements. These reform movements, which developed largely in response to the British colonial presence and engagement with Christianity, focused a great deal on the issues of women. Two features of these early movements are worth noting. First, in spite of being strongly patriotic, the leaders of these movements were able to work collaboratively with Westerners (chiefly, British officials) in introducing landmark reforms that had positive implications for women's lives. Second, even though arguing passionately for reforms within Hindu society, the leaders generally supported their arguments drawing attention to passages from ancient texts, which they re-interpreted in the light of modernity. The legal movement abolishing the practice of Sati, which was carried out till 1918, is considered a landmark in the history of modern Nepal. Further, referring to ancient mystical texts, the Upanishads, which recommend eternal liberation of the soul rather than temporary residence in heaven, Roy suggested that since sati only ensures the latter, it is not a spiritual practice of great merit. Mahatma Gandhi advocated looking at the smritis (Hindu sacred texts and code books) in light of the principle of nonviolence, which in his view, included equal rights for women. He suggested that all that was repugnant to the moral sense in these texts, should not be viewed as divinely inspired. He also referred to Hindu woman saint princess Mira as a model of bravery to support women's participation in public life. A large number of women joined the freedom movement and social reform work led by Gandhi. Like early reform movements, the re-interpretive lens of Gandhian movement also privileged the religious concepts of the elite rather than popular practices of Hindu women.

\section{Analysis of the information}

Despite belated start of more proactive, systematic and governmentsupported cooperative initiatives, the first pioneers in the field of women leadership emerged relatively soon after the restoration of democracy in 1991. Civic organizations, which faced many obstacles and little support, have developed in many cases particularly due to various international resources. Tradition also played an important positive role, however, faster 
dissemination of women's involvement in cooperatives and cooperative management as one of its part was hampered by expectations of some male dominant organizations and entrepreneurs that the state was there to take care of these activities (Bartosova, 2006).

Even though women's empowerment on financial mobilization and debate about it was not in Nepal as popular as in older western democracies, women's leadership role effectiveness has steadily becoming more and more popular and also a group of involved cooperatives has been growing. Today many cooperatives, particularly the large ones, present their achievements in women's empowerment and other related documents as well as on pages of organizations promoting women's leadership role. Increasing interest in financial mobilization in Hindu tradition, in 2004 in the survey $76 \%$ of surveyed cooperatives claimed to be involved at least in some women's lead roles (the most frequently towards share members); in 2007 it was almost 90 \%. Women's awareness has also been increasing.

\section{Theoretical perspectives}

The different aspects of the theory starting with the conceptualisation of individual has been considered for decision-making by actors and followed by an elaboration on belief systems and decision-making. The concept of organizational development stresses the growth of the individual as one of its major objectives. It would be obvious to illustrate that an individual manager should be an expert in all roles, and should have some background and general knowledge in all of the areas and expertise in a number of specific areas, depending upon the nature and requirements of the job.

Afful (2002) has emphasized that from the organizational development perspective, the manager should play the roles to act as communicator, integrator, planner and decision maker, organizational designer, innovator, problem solver, coach and counselor, teacher and learner, advocate and as a model of style. These roles have been given with equal emphasis and all these roles are required for the top level as well as the middle managers. There is no evidence mentioned whether these roles are the key success factors of successful managers to lead an organization. The major and minor roles are differentiated among them. Still there exists a question that which roles play the most in leading and managing the organization, and whether their extent differs from organization to organization, time to time, place to place and context to context. 


\section{Leadership roles}

Hersey and Blanchard (2002) have claimed that there are two aspects of situational team leadership roles under task and relationship behaviors. In each leadership style, helping roles as well as hindering roles have been mentioned. Figure 1 illustrates the comprehensive version of the situational leadership model.

Figure 1: Comprehensive version of the situational leadership model

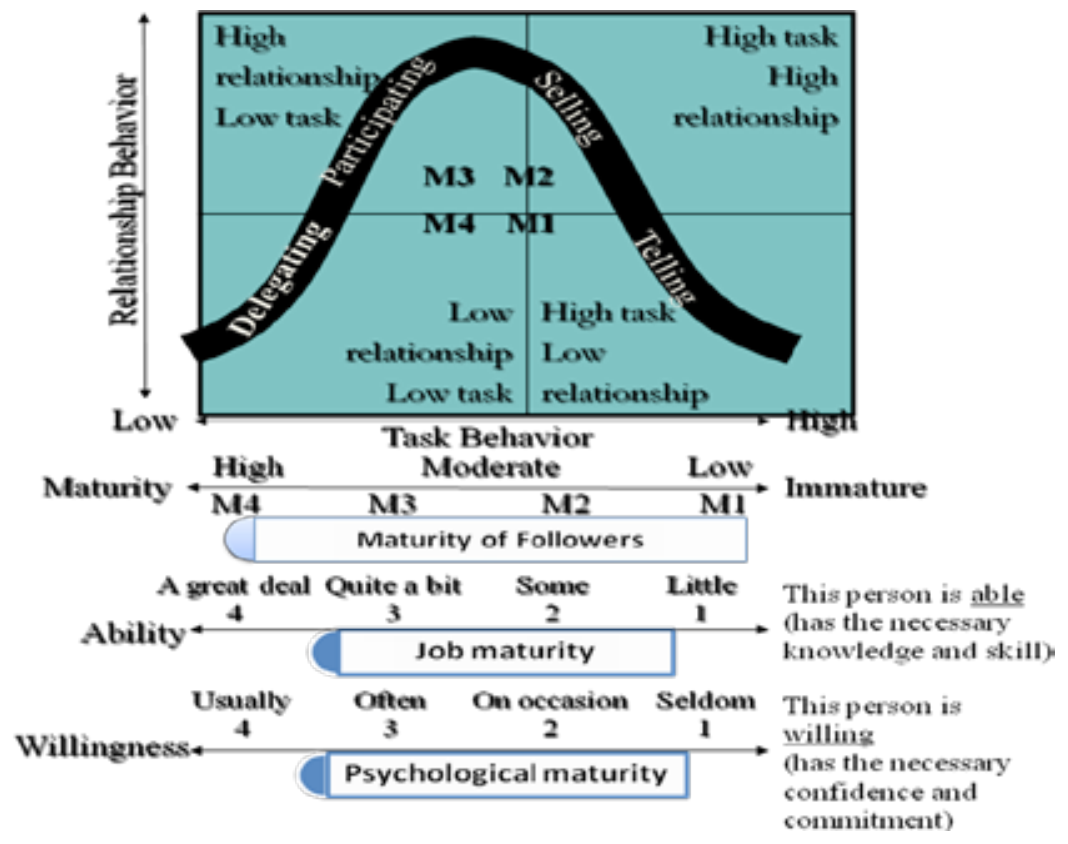

Shown in the figure 1 is a situational leadership curve that brings together the discussion for diagnosing the level of readiness, adapting the high probability leadership styles, and communicating these styles effectively to influence behavior. Implicit in situational leadership is the idea that a leader should help followers grow in readiness as far as they are able and willing to go (Rijal, 2004).

Situational leadership contends that strong direction (task behavior) with followers with low readiness is appropriate if they are to become productive. Similarly, it suggests that an increase in readiness on the part of people who are somewhat unready should be rewarded by increased positive reinforcement and socio-emotional support (relationship behavior). As 
followers reach high levels of readiness, the leader should respond not only by continuing to decrease control over their activities but also by continuing to decrease relationship behavior (Hersey \& Blanchard, 2002).

\section{Hindu traditional texts and financial management policies}

The study is also interested in the institutional factors which influence women's leadership role to involve in financial mobilization under Hindu tradition in the past and present in cooperative sector. The institutional factors influencing the preference for policy instruments, especially with respect to women's role, will be also identified and elaborated. A basic assumption of the study is that different institutional Hindu traditionaleconomic contexts influence implementation and diffusion of women's role effectiveness in the cooperative sector, but also with respect to preferences for policy instruments on the macro layer. In other words, the institutional setup of a constituency might influence the implementation likelihood of macro-policy instruments associated with women's leadership in financial mobilization such as self- and co-regulation schemes.

Lochtefeld (2002) introduced a promising approach to institutional factors and their influence on policy-making and implementation the 'goodness of fit' of policies and institutional structures. They argue that central (core) institutional traditions of a constituency are difficult to change and if the misfit with a certain policy or policy instrument is too big than institutional (systemic resistance is the consequence. The central institutional elements in their study are the level of trust within a society, distribution of resources, political culture and tradition with respect to policy making, constitutional structure, fundamental sociocultural values, and the reform capacity of a constituency. According to the theory, if these institutional elements are confronted with exceedingly high demands for adaptation or change by a policy or policy instrument then resistance may be the result. However, policy misfit does not necessarily lead to implementation failure.

DeCenzo and Robbins (2003) argues that domestic actors are able to exert enough pressure on institutions to change or adjust to the new requirements. It has to be stressed at this point that the aim of the study on women's leadership is not to test the theory of Lochtefeld but to use their insights on intuitional settings influencing policy-making.

The Advocacy Coalition Framework (ACF) together with goodness of fit theory form a solid basis for identifying the core institutional variables 
(level of trust within a society, political culture and tradition with respect to policy-making, and the constitutional structure) of importance with respect to women empowerment and policy-making. It is assumed that these institutional factors considerably influence the level of impact the modern concept of women's leadership can have on interactions between business and public authorities. Institutional theory argues that the scope of policy change is constrained by the existing institutional arrangements, the institutions' roots and routes (Drucker, 1998).

From the industrial revolution to recent years, social objectives have been almost entirely the responsibility of government. Social and cultural movements, activities of non-profit organizations and pressure groups led to the mobilisation of public opinion demanding from corporations to demonstrate a socially responsible stance towards inclusion. Since the earlier twentieth century, countries all around the globe has developed legislations to control the relationship between employee and the cooperative, health and safety at work, issues of environmental interest, discrimination and equal opportunities at workplace.

A question of interest therefore is, whether government should assist business to exceed its legal obligations and hence commit itself to socially responsible behaviour. Interestingly, government might play a role to encourage and promote the social responsibility of business. Researchers from the World Bank have identified four principal public sector roles in relation to women's leadership that are mandating, facilitating, partnering and endorsing roles. Four principal public sector roles in strengthening women's empowerment are the following:

Mandating role: In their mandating role, governments at different levels define minimum standards for business performance embedded within the legal framework. Examples include establishment of emission limit values for particular categories of industrial installations, or requirements for cooperative directors to take particular factors into account in their decisionmaking. Even mandating activity can drive industrial innovation and best practice. For example, the familiar notions that cooperatives should apply the best available techniques, best available technology, or the best practicable environmental option to manage emissions allow for the fact that what is best will change over time with technological innovation and technology transfer.

Facilitating role: Setting clear overall policy frameworks and positions to guide business investment in women's empowerment, development of 
nonbinding guidance and labels or codes for application in the marketplace, laws and regulations that facilitate and provide incentives for business investment in women's empowerment by mandating transparency or disclosure on various issues, tax incentives, investment in awareness raising and research, and facilitating processes of stakeholder dialogue.

Partnering role: Combining public resources with those of business and other actors to leverage complementary skills and resources to tackle issues within the women empowerment agenda, whether they are participants, convenors, or catalysts.

Endorsing role: Showing public political support for particular kinds of women's leadership practice in the marketplace or for individual cooperatives; endorsing specific award schemes or non-governmental metrics, indicators, guidelines, and standards; and leading by example, such as through public procurement practices (Olivelle, 2013).

Almost 75 percent of survey respondents stated that among the cooperatives with which they are most familiar, women comprise less than 50 percent of the co-operative board. A quarter of those same respondents reported that women occupy less than 10 percent of the board. About 65 percent of respondents estimated that women occupy less than 50 percent of management positions. A quarter of all respondents estimated that women hold 10 percent or less of managerial positions. Despite the scarcity of women in leadership roles, over half of all survey respondents stated that women comprise over 50 percent of membership and over 50 percent of the clientele. As these figures suggest, women are among the most involved in and served by co-operative organizations, but among the least likely to hold high-ranking and decision-making roles. If co-operatives are truly to be guided by representative leaders and provide opportunities for women to develop their leadership capacities, more work must be done to improve the promotion of women from membership to governance and management levels. 
Figure 2: Percentage of Women in Cooperative Leadership

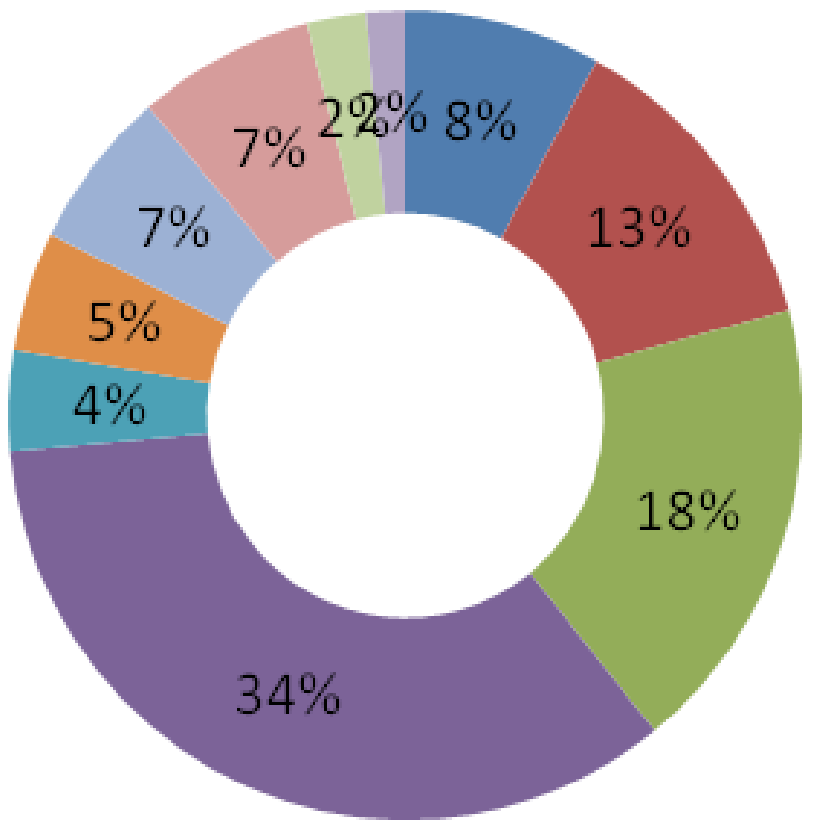

\section{0-10 $\square 10 \_20 \square 20-30 \square 30-40 \square 40-50$ $\square 0-60 \quad 60-70 \square 70-80 \square 80-90 \square 90-100$}

Source: DoC, Status Report, 2017

Consumer co-operatives facilitate broader and larger membership because they offer services related to daily occupational activities, such as food shopping. These activities are traditionally undertaken by women, which may help to explain women's higher participation in consumer cooperatives. Finance and agriculture, on the other hand, are historically male-dominated economic sectors. This imbalance helps to explain women's low representation in co-operatives in this sector, particularly at the leadership level. However, agriculture has been increasingly feminized; women have a substantial presence as labourers and in self-employment. In theory, women's engagement in agricultural cooperatives should be on the rise. Going forward, more work and research 
must be done to understand the ways in which gender equality can be achieved within these important sectors. To address the shortage of women in leadership roles, interviewees recommend that management reach out to women members to encourage their involvement and gender equality orientation. In addition, training should be extended to the current leadership of co-operatives. Interviewees also recommended that co-operative management create supportive mechanisms, such as on-site child care services, which would enable women to participate in delegate structures while balancing other commitments that would otherwise limit their participation (Simkhada, 2004).

The theoretical debates and the political discussions around the notion of government's role in women's empowerment suggest that there are two prevailing perspectives of women leadership which consequently facilitate the development of two competing women leadership models. As leadership is the heart of any organization to operate their activities as blood circulation into the body, organizations without good leadership can not flourish properly. In the context of cooperative leadership, the leadership being offered by women is seen no less effective in comparison with male. As people are saying that women have crucial role to develop the nation long. Similarly, in cooperative sector there would be the important of women leadership empowerment. To impose women involvement in cooperative women leadership should handle the organization by showing their management skill in field. Recently, Nepalese cooperatives have started to practise women's leadership position. Some cooperatives seem to involve for their own prosperity of their women member rather than the community members. But because of different defficiencies, this concept has not yet been widely accepted in Nepal.

\section{Woment leadership framework in cooperatives}

The women leadership framework constructed based on the analysis of the information, describes the phenomenon used for the study. Knowledge and practice might depend on different independent variables (previous experience, behavior change communication program, information communication technology, age, educational status, ethnicity, occupation and religions). If all these variables affect positively, it increases the knowledge and practice regarding optimum use of cooperative services, and sustainability of women's leadership within the philosophy of social security. 
This result is the improvement of women's leadership empowerment in cooperative sector in the community. If the cooperative members decided to manage the effective role of women's leadership, it would help to reduce the poverty consequences and social inclusion may be ensured and promotion of gender equality can be uplifted.

Figure 3: Women Leadership Framework in Cooperatives

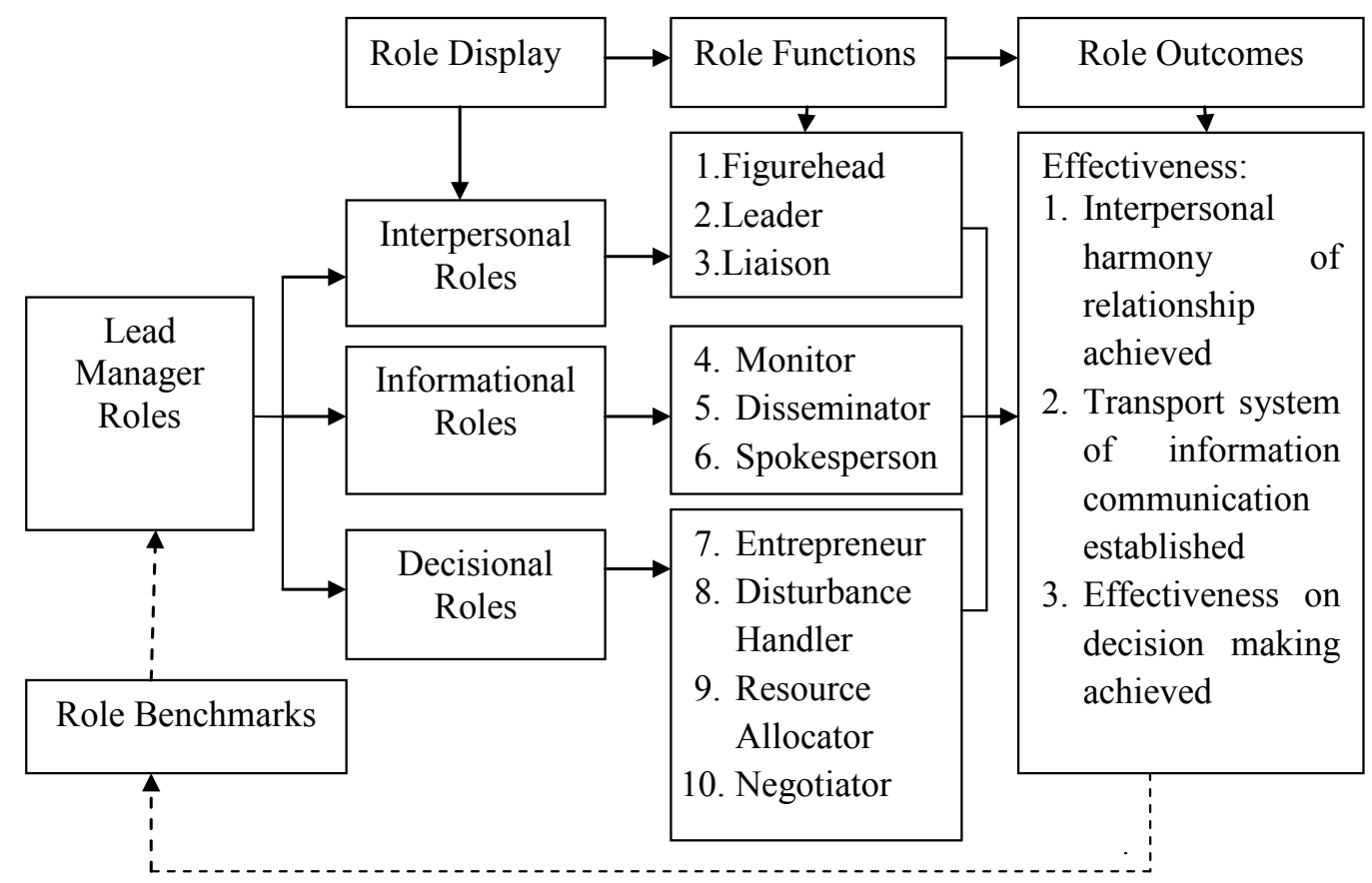

The figure 3 shows that the relationship with socio-demographic variables, knowledge, practice and attitude, the delay factors contributing to reduce or increase the role effectiveness of women leadership and improvement of inclusion under present Hindu tradition. The practice on women's leadership on financial mobilization as well as inclusion and participation of different stakeholders including poor and disadvantaged people may contribute the effective management of the iclusive participation within cooperative management. The knowledge, practice and attitude are assessed and reflection from the data demonstrates the impact that may lead to improvement of women's leadership under Hindu tradition. 


\section{Conclusion}

Nepalese Hindu traditions show the significant potential as women's effective role for financial mobilization in the family. This is true for all regions of Nepal, including the Hills, Mountains and Terai region. Nepalese cooperative society is almost entirely financed via member savings and equity. The rate of interest earned on loans is a key factor affecting profitability. Nepalese Hindu society incurs low administration costs and generate significant member saving even in poor, remote communities. In light of these findings, the government should adopt moral and resource support strategies that build on women's ability to mobilize savings. The government and donors should give attention to microfinance institution building and should not provide concessionary funding. While cooperatives may sacrifice short term growth and outreach to achieve financial sustainability, they serve thousands of poor households in remote areas and provide a variety of microfinance services for the long term. The study noted embezzlement of funds for some of successful women leaders. Moreover, failure to comply with the guidelines and regulations by family members, and management when issuing loans contributed to loans default risk. This study recommends that exclusion should not be entertained in family business. Female involvement should also be made sure that they abide by their regulations.

\section{References}

Afful, K. (2002). Effective management in the South, $\left(2^{\text {nd }}\right.$ Edition). Kathmandu: Ekta Publishers Pvt. Ltd.

Bartosova, Z. (2006). Benchmarking of CSR. Amsterdam: Amsterdam University Press.

CBS (2011). Nepal National Population and Housing Census 2011. Kathmandu: Central Bureau of Statistics.

DeCenzo, D. A. \& Robbins, S. P. (2003). Personnel/human resource management, (3 ${ }^{\text {rd }}$ Edition). New Delhi: Prentice Hall of India Pvt. Ltd.

DoC (2017). Status report of Nepalese cooperatives. Kathmandu: Department of Cooperatives.

Drucker, P.F. (1998). Management's new paradigms. Forbes, Oct. 5, 1998, pp 152-530.

Hersey, P. and Blanchard, K. (2002). Life cycle theory of leadership: Revisiting the life cycle theory or leadership. Massachusetts: EBSCO Publishing.

ILO (2009). Resilience of the cooperative business model in times of crisis. Geneva: International Labour Organization.

Kothari, C.R. (2004). Research methodology, method of technique Determination of sample size. Second Edition. New Delhi: New Age International Publishers.

Lochtefeld, J. (2002). Smrti: The illustrated encyclopedia of Hinduism, Vol. 2: N-Z, Rosen 
Publishing. ISBN 9780823931798, Pp 656 and 461

Nayarayan, M.G.S. (1999). Consolidation of agrarian society. Perspectives on Kerala historyThe Second Millennium Ed. P.J.Cherian. Kerala: Council for Historical Research.

Nelson, C. \& Thomsen, T. (2010). Learning from clients: Assessment tools for microfinance practitioners. Washington, D. C.: The Small Enterprise Education and Promotion Network.

Olivelle, P. (2013). King, governance, and law in incient India: Kautilya's arthasastra. New York: Oxford University Press.

Rijal, C.P. (2004). Leadership readiness for TQM in schools. An unpublished Ph. D. Thesis, Kathmandu University.

Simkhada, N. R. (2004), Innovations in Nepal's microfinance sector and benefits for Asia: A case study of four savings and credit cooperative societies operating in the hills of Nepal. Paper Presented to the Workshop on Sharing Microfinance Resources and Knowledge in South Asia. February 24. 